\title{
Genetic counselling for handicapped school leavers
}

\author{
M VOWLES
}

From the Department of Paediatrics, Royal Devon and Exeter Hospital (Heavitree), Exeter

SUMMARY A total of 287 school leavers with 299 unassociated handicaps from seven specia $\vec{\rightleftarrows}$ schools for physically handicapped, visually handicapped, and deaf children were given genetie counselling from 1973 to 1979 . The practical aspects of running this project are described. The risk艿 needed were those of having an affected child: $54(18 \cdot 8 \%)$ were given a high risk (greater than 1 ini 10), $89(31.0 \%)$ were given a moderate risk ( 1 in 10 to 1 in 40$), 69(24.0 \%)$ were given a low risk (less than 1 in 40$)$, and $83(28.5 \%)$ were told that their risk was the same as that of the generats population. Of the 299 total handicaps, $25(8 \cdot 4 \%)$ were thought to be autosomal dominant condio tions, $38(12 \cdot 7 \%)$ to be autosomal recessive conditions, and $8(2 \cdot 7 \%)$ to be $\mathrm{X}$ linked conditions? Empirical risks were given for $145(48 \cdot 5 \%)$ diagnoses, and general population risks for the remaining $83(27 \cdot 7 \%)$.

Genetic screening seeks to identify in a population those persons with a genotype associated with incipient or established disease or which may lead to specific genetic disease in their offspring. Not only is there mass screening in the UK and some other countries for phenylketonuria in the newborn and Rhesus negativity in pregnant women, but also during the last decade there have been some notable programmes for selective screening of adult subpopulations known to be at risk of having a child with a genetic disorder; for example, the detection of Down syndrome in the fetuses of older mothers, the identification of carriers of the Tay Sachs allele in high school students in Montreal, ${ }^{1}$ and of carriers of the thalassaemia allele in intermediate schools in Latium. ${ }^{2} 3$

Just as some of the participants in these programmes may run the risk of having an affected child, so may a proportion of pupils in special schools for the handicapped. Moreover they will eventually disperse into a society where they will not automatically receive genetic advice. A service offering genetic counselling to handicapped school leavers was accordingly started in Exeter in 1973, some five years after the institution of a genetic advisory service in the area when medical personnel in both hospital and community practice were already aware of the benefits provided by the service.

\section{Probands}

The index patients came initially from St Loye's residential college for further education and training Received for publication 2 October 1980 of the disabled and from the residential West of England School for the Visually Handicapped, botho situated in Exeter. In 1974, school leavers from the Royal West of England School for the Deaf, alse residential, were included. In 1975 a similar services was started at two non-residential schools in Plymouth, one for physically handicapped (Woodڤ్ lands) and the other for deaf children (Hartleye House), and in 1977 a further non-residential schoof for the physically handicapped in Torquay (Steps Cross) was included. Finally, Dame Hannah Rogers residential school for the handicapped at Ivybridge has been included since 1978. The numbers and

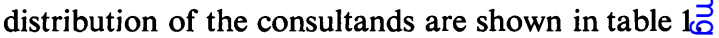

\section{Approach and methods}

This project would have been difficult without thê enthusiastic support of the headmasters and medica? officers of the schools concerned, which has been maintained throughout the seven years since is

TABLE 1 Handicapped school leavers counselled

\begin{tabular}{|c|c|c|c|c|c|c|c|c|}
\hline & 1973 & 31974 & 41975 & 51976 & 61977 & 71978 & 81979 & 9 Total \\
\hline $\begin{array}{l}\text { Physical handicap } \\
\text { (Exeter) }\end{array}$ & 2 & 8 & 12 & 11 & 11 & 17 & 4 & 65 \\
\hline $\begin{array}{l}\text { Partially sighted } \\
\text { (Exeter) }\end{array}$ & 9 & 12 & 14 & 11 & 8 & 6 & 16 & 76 \\
\hline Deaf (Exeter) & & 3 & 6 & 16 & 12 & 15 & 27 & 79 \\
\hline Deaf (Plymouth) & & & 3 & 3 & 1 & 4 & 5 & 16 \\
\hline $\begin{array}{l}\text { Physical handicap } \\
\text { (Plymouth) }\end{array}$ & & & 4 & 3 & 1 & 5 & 4 & 17 \\
\hline $\begin{array}{l}\text { Physical handicap } \\
\text { (Torquay) }\end{array}$ & & & & & 6 & 11 & 11 & 28 \\
\hline $\begin{array}{l}\text { Physical handicap } \\
\text { (Ivybridge) }\end{array}$ & & & & & & 1 & 5 & 6 \\
\hline Total & 11 & 23 & 39 & 44 & 39 & 59 & 72 & 287 \\
\hline
\end{tabular}


started. At four of the schools, the Royal West of England School for the Deaf (Exeter), the West of England School for the Visually Handicapped (Exeter), Hartley House School for the Deaf (Plymouth), and Steps Cross School for the Physically Handicapped (Torquay), all school leavers are offered an appointment irrespective of whether their handicap is congenital or acquired. At St Loye's College for the Disabled (Exeter) the problems are assessed by an experienced medical officer who then refers only those who have disorders or defects with possible genetic implications, while the others are reassured as part of their routine care. A similar course of action is followed both at Woodlands School for the Physically Handicapped (Plymouth) and Dame Hannah Rogers School for the Physically Handicapped (Ivybridge) after the diagnoses and records have been checked.

A few weeks before counselling takes place the headmaster in each school writes to the parents of the pupils concerned to explain the purpose of genetic counselling, request their permission for the consultation, and invite them to attend. Out of 287 pupils the parents of only four have withheld permission. Attendance rate by the parents is low, especially at the residential schools where they may have to travel up to 200 miles, well beyond the Devon county boundary.

A short proforma is enclosed with this letter requesting details of family history and consanguinity in first and second degree relatives of the child. Although this information is not relied upon, it may supplement and corroborate that provided by the Local Education Authority, the school, and hospital medical records all of which are studied before consultation. The next and very important step is for the medical officers or headmasters to discuss genetic counselling with the pupils concerned either in a group situation or with separate individuals or sometimes both, a few days before the consultation.

The first consultands in 1973 were seen in a small paediatric research unit attached to the Royal Devon and Exeter Hospital (Heavitree). Difficulties in communication were soon experienced with the deaf school leavers and it seemed unlikely that the odds were being understood in every case. All counselling sessions were therefore moved to the various school premises where, if the parents were not present, a teacher attended and, if necessary in the schools for the deaf, acted as an interpreter. This had a further advantage in that discussions subsequently took place between teachers and consultands and although a further interview has always been offered this has not yet been taken up.

\section{Counselling given}

The risks that were needed for the 287 school leavers seen (appendix) were those of having an affected child. Fifty-four $(18.8 \%)$ were given a high risk (greater than 1 in 10$), 89(31.0 \%)$ were given a moderate risk ( 1 in 10 to 1 in 40$), 69(24.0 \%)$ were given a low risk (less than 1 in 40$)$, and $83(28.5 \%)$ were told that their risk was the same as that of the general population. These figures include six consultands considered to have two unassociated conditions in different risk categories (Nos 26, 53, $124,168,203,139)$, and two where the consultand was at risk of developing and subsequently passing on a heritable condition (Nos 1 and 28). Furthermore, there were four consultands considered to have two unassociated conditions in the same risk category (Nos 54, 81, 89, 103) (appendix).

Twenty-five (8.4\%) school leavers (Nos 1, 2, 3, 5, $6,20-25,28-30,32-38,40,53,54)$ were thought to have an autosomal dominant condition with up to a 1 in 2 risk of having an affected child. One of these (No 54) had two unassociated conditions each having up to a 1 in 2 risk, and two more (Nos 23 and 28) were at risk of developing an autosomal dominant condition in later life. Modifications of risk were discussed for those conditions where manifestation is variable or penetrance incomplete.

Thirty-eight $(12.7 \%)$ consultands were considered likely to have an autosomal recessive condition. Of these, seven $(0.2 \%)$ were thought to have only a moderate risk for their children unless they married a relative or a person who was either heterozygous or homozygous for the same abnormal gene (Nos 113$116,118,122,139)$. The remaining $31(10 \cdot 8 \%)$ were given a low risk with the same proviso regarding marriage partners (Nos 124, 141, 168-172, 174-186, 189-192, 194-196, 199, 201, 204, 205). Three (Nos $124,168,203)$ had a further handicap for which they were given the appropriate risks; 'moderate' for case No 124 and 'as for the general population' in Nos 168 and 203. Also in this cohort of 38 consultands, one (No 172) is likely to be infertile and thus there would be no risk to his offspring. It was not deemed a psychologically opportune age at which to discuss this problem and he was advised to seek further counselling before marriage.

$\mathrm{X}$ linked genes were considered to be the cause of the handicap in eight $(2.7 \%)$ cases. Three of these (Nos 117, 120, 121) were classified in the moderate risk group and five (Nos 140, 173, 180, 187, 200) were given a low risk for their offspring to be affected, although they were told that their daughters would all be carriers of the abnormal gene.

Empirical risks were the basis of genetic counselling 
in a further $145(48.5 \%)$ probands. Thirty $(10.5 \%)$ were given a high risk (Nos 4, 7-19, 26, 27, 31, 39, 41-52) and $79(27.5 \%)$ were given a moderate risk (Nos 23, 26, 28, 53, 55-112, 119, 123-138). Three of these (Nos $81,89,103)$ had two unassociated conditions each with a moderate risk.

The handicaps affecting the remaining $83(27 \cdot 7 \%)$ probands (Nos 139, 168, 203, 208-287) were thought to be acquired and they were reassured that the risks for their progeny were the same as for the general population. However, a further eight not only had a handicap in this category but also an unassociated one which was not acquired. Four (Nos 23, 26, 28, 53) have already been included in the list of autosomal dominant conditions, three (Nos 124, 139, 168) in that of autosomal recessive conditions, and one (No 203) was given an empirical risk (table 2).

The many different handicaps affecting the consultands from the seven schools and the even greater diversity of aetiological factors have been reduced to three major groups: physically handicapped, deaf, and visually handicapped. One hundred and nine consultands in the 'physically handicapped' group were given the following risks: $20(18.3 \%)$ were given a high risk, $43(39 \cdot 4 \%)$ were given a moderate risk, and $31(28.5 \%)$ a low risk. The remaining $15(13.8 \%)$ were reassured that the risks for their children are the same as for the general population (table 3). The 97 consultands in the 'deaf' group were given the following risks: nine $(9.2 \%)$ were given a high risk, $35(36 \cdot 1 \%)$ were given a moderate risk, and two $(2 \cdot 17 \%)$ a low risk, while $51(52 \cdot 6 \%)$ consultands were reassured that their children would have no added risk (table 4). The third group, 'visually handicapped', consisted of 81 consultands of whom $25(30.9 \%)$ were given a high risk, seven $(8.6 \%)$ a moderate risk, and 35 $(43.2 \%)$ a low risk. The remaining $14(17 \cdot 3 \%)$ were reassured that their offspring are unlikely to be similarly affected (table 5).

It became apparent at an early stage in this project that the youngsters were unable to evaluate risk figures at the age of 16 years. For this reason terms of 'high', 'moderate', or 'low' chances of their having
TABLE 3 Risk groups, physically handicapped

\begin{tabular}{lr}
\hline High & \\
$>1$ in 10 & $20(18 \cdot 3 \%)$ \\
$\begin{array}{l}\text { Moderate } \\
1 \text { in } 10 \text { to } 1 \text { in } 40\end{array}$ & $43(39.4 \%)$ \\
Low & $31(28 \cdot 5 \%)$ \\
$<1$ in 40 & $15(13.8 \%)$ \\
General population & $109(100.0 \%)$ \\
$\quad$ Total & \\
\hline
\end{tabular}

TABLE 4 Risk groups, deaf

\begin{tabular}{lrr}
\hline High & & \\
$>1$ in 10 & 9 & $(9 \cdot 2 \%)$ \\
Moderate & & \\
1 in 10 to 1 in 40 & 35 & $(36.1 \%)$ \\
Low & & \\
$<1$ in 40 & 2 & $(2.1 \%)$ \\
General population & $51 \quad(52.6 \%)$ \\
$\quad$ Total & $97(100.0 \%)$
\end{tabular}

TABLE 5 Risk groups, visually handicapped

\begin{tabular}{lcr}
\hline High & & \\
$>1$ in 10 & 25 & $(30.9 \%)$ \\
$\begin{array}{l}\text { Moderate } \\
1 \text { in } 10 \text { to } 1 \text { in } 40\end{array}$ & 7 & $(8.6 \%)$ \\
Low & & \\
$<1$ in 40 & 35 & $(43.2 \%)$ \\
General population & $14(17.3 \%)$ \\
$\quad$ Total & $81(100.0 \%)$
\end{tabular}

affected offspring were used. The actual odds, if $\stackrel{\mathbb{2}}{\square}$ known, were occasionally given to a consultand $\overrightarrow{\overrightarrow{0}}$ where it seemed helpful and were quoted in the 3 reports sent to the School Medical Officers and the family doctors for inclusion in school and NHS medical records.

The possibility that one handicapped person might marry another similarly affected or with a handicap of a different nature was raised at each interview and the consultands were strongly advised to seek further $O$ counselling if such a situation should arise. A further consultation before marriage was also recommended if the handicap was such that it was difficult to give $\frac{D}{2}$ an accurate diagnosis at the time of leaving school.

Finally contraception and the possibilities of $\tilde{\sigma}$

TABLE 2 Genetic basis of risk estimation (287 probands; 299 unrelated diagnoses)

\begin{tabular}{|c|c|c|c|c|c|c|}
\hline Risk & Autosomal dominant & Autosomal recessive & $X$ linked recessive & Empirical & Acquired & Total \\
\hline $\begin{array}{l}\text { High } \\
>1 \text { in } 10 \\
\text { Moderate }\end{array}$ & 25 & 一 & - & 30 & - & $55(18.4 \%)$ \\
\hline $\begin{array}{l}1 \text { in } 10 \text { to } 1 \text { in } 40 \\
\text { Low }\end{array}$ & - & 7 & 3 & 82 & - & $92(30 \cdot 8 \%)$ \\
\hline$<1$ in 40 & - & 31 & 5 & 33 & - & $69(23.1 \%)$ \\
\hline General population & - & - & - & - & & $83(27.7 \%)$ \\
\hline Total & $25(8.4 \%)$ & $38(12 \cdot 7 \%)$ & $8(2.7 \%)$ & $145(48.5 \%) 3$ & $83(27 \cdot 7 \%)$ & $299(100.0 \%)$ \\
\hline
\end{tabular}


antenatal diagnosis were discussed briefly when pertinent, but options such as adoption and AID were not introduced.

\section{Discussion}

In assessing the correct risks there were two problem areas. Firstly, how should one advise the isolated cases of conditions thought to be the result of autosomal dominant, autosomal recessive, or $\mathbf{X}$ linked recessive genes? Nine (Nos 1-4, 32, 33, 35-37) of the 23 autosomal dominant group were isolated cases although factors such as illegitimacy or 'formes frustes' could not be ruled out as the parents were not interviewed or examined. Two (Nos 183, 184) of the 38 assessed as being homozygous for autosomal recessive genes could be heterozygous for $\mathrm{X}$ linked recessive genes, but in this event a low risk for their children is also appropriate, with the proviso that their daughters would be obligate carriers and so further genetic counselling was advised both for them and their female offspring. Myopia affecting case No 201 could be polygenic/multifactorial instead of autosomal recessive but once again a similar risk, this time 'low', would apply. Secondly, the group of 142 probands given empirical risk figures comprises conditions such as spina bifida where family studies have been done, conditions such as arthrogryposis where no such studies exist, and some cases where, although the clinical findings were described, a precise diagnosis was not made in terms of aetiology, for example, optic atrophy (No 31). Heterogeneity led to some consultands being given an empirical risk figure when in fact their handicap could have been the result of a single gene. One feels uneasy that such a large proportion $(48 \cdot 57 \%$ ) of these handicapped young people were given empirical risk figures, although those in the high risk group $(10 \%)$ were based on family studies.

None of the 287 probands had been given any previous genetic counselling. There was no evidence in any of the records examined, whether NHS file, Local Authority, school or hospital records, that any assessment had been made of the genetic component of the various handicaps. Most of those whose handicap was the result of a non-genetic cause, for example, rubella or meningitis, were aware of the aetiology, but even some of these were unsure whether their children might or might not be affected. In the 14 cases where there was a family history of a dominant condition only two had been made aware by their families of a high risk to their offspring. One of these repeated throughout the interview "My mother says I must not get married"!

Overall, it was difficult to assess how many had been previously concerned about the possible risks to their offspring, as attention had been drawn to this by the teaching of elementary genetics in biology lessons and by the preparatory talks by the headteachers shortly before the genetic counselling interview, but a number were obviously glad of the opportunity to discuss the matter. Moreover, they were made aware that genetic counselling is available for themselves, their relatives, and for other handicapped persons with whom they may well come in contact. Indeed, this was initiated immediately for the sibs of consultands with autosomal dominant and recessive conditions and for both male and female first degree relatives of those who had an $\mathrm{X}$ linked condition.

Out of 287 school leavers approached, the parents of only four withheld permission, a $99 \%$ acceptance rate. This high uptake reflects not only the tactful approach made by the head teachers to both parents and pupils, but also the desire on the part of the parents for their affected child to discuss the problem with a genetic counsellor. It compares favourably with the $75 \%$ participation rate reported in both 'A Study of Tay-Sachs Screening Among High School Students' by Clow and Scriver ${ }^{1}$ and that of $70 \%$ reported in 'First Premarital Screening of Thalassaemia Carriers in Intermediate Schools in Latium' by Silvestroni $e t a l,{ }^{2}$ which increased to $76 \%$ four years later, ${ }^{3}$ although the genetic problems and implications are so different that perhaps a comparison is invidious. All three projects, however, share the importance of offering genetic advice premaritally and at a time when the subjects still have the support of an understanding school staff should they be distressed by the advice given. Furthermore, in the case of the UK, the advice is incorporated in their NHS general practitioner and hospital records for future reference.

From table 6 it can be deduced that in 1978 over 3000 pupils known to be handicapped, physically or visually or in their hearing or a combination of these, were in their final school year at special schools. They formed a 'captive' group where genetic counselling might have been of benefit not only to the subjects concerned but also in a few instances to their relatives. Moreover, by improving the awareness of genetic risks before reproduction takes place there is a real possibility that the incidence of certain

TABLE 6 Handicapped pupils in England and Wales (1978) aged 5 to 16 years

\begin{tabular}{lr}
\hline Physically handicapped & 17000 \\
Deaf and partially hearing & 11600 \\
Blind and partially sighted & 4000 \\
Total & 32600 \\
Number of school leavers (approx) & 3200 \\
\hline
\end{tabular}


severe genetic disorders in the population might be reduced. Such long term effects will not be evident for many years; however, a follow-up has been started of those probands seen in 1973, now aged 22, similar to those of Carter et $a l^{4}$ and Emery et al..$^{5}$ At follow-up probands are asked whether they understood the risk assessment given to them, whether it affected their feelings about having children, and whether their feelings have changed in the last seven years. At the same time pedigrees are updated and, where necessary, previous genetic advice is amended in the light of recent advances.

The author is grateful to Mrs Ann Hoskins for her help in organising the project, to Mrs Coram and Mrs Hoskins for their secretarial help, and to Dr Sarah Bundey for reading this manuscript.
References

1 Clow CL, Scriver CR. The adolescent copes with genetic screening; a study of Tay-Sachs screening amongst high- $\mathscr{\infty}$ school students. In: Kaback MM, ed. Tay-Sachs disease: 0 screening and prevention. New York: Liss, 1977;381-93.

2 Silvestroni E, Bianco I, Graziani B, Carboni C, d'Arca $\overline{\bar{D}}$ SU. First premarital screening of thalassaemia carriers in $\vec{D}$ intermediate schools in Latium. $J$ Med Genet 1978;15: 202-7.

3 Silvestroni E, Bianco I, Graziani B, Carboni C, d'Arca के SU. Screening of thalassaemia carriers in intermediate $\vec{\circ}$ schools in Latium: results of four years' work. J Med Genet 1980;17:161-4.

4 Carter CO, Evans KA, Fraser Roberts JA, Buck AR. Genetic clinic. A follow-up. Lancet 1971 ; i:281-5.

5 Emery AEH, Raeburn JA, Skinner R, Holloway S, Lewis P. Prospective study of genetic counselling, Br MedJ 1979;i:1253-6.

Requests for reprints to Dr M Vowles, Department of Paediatrics, Royal Devon and Exeter Hospital (Heavitree), Gladstone Road, Exeter EX1 2ED.

APPENDIX The risks quoted are those which related to particular families and which were considered appropriate at the time of counselling. They should not be regarded as applicable to all families with similar diagnoses.

\begin{tabular}{|c|c|c|c|c|c|c|c|c|}
\hline & Name & Sex & Handicap & Cause & Family history & Sibs & & \\
\hline \multicolumn{9}{|c|}{ HIGH RISK (GREATER THAN 1 IN 10) } \\
\hline 1 & RB & $\mathbf{M}$ & Ectrodactyly (R) & - & - & $6 \square$ & 2 & \\
\hline 2 & EF & $\mathbf{F}$ & Achondroplasia & - & - & $1 \square$ & 8 & 00 \\
\hline 3 & JD & $\mathbf{F}$ & Achondroplasia & 一 & $-\ldots$ & \multirow{3}{*}{\multicolumn{3}{|c|}{$\begin{array}{l}\text { Unknown } \\
1 \square\end{array}$}} \\
\hline 4 & MB & $\mathbf{F}$ & Dystonia musculorum deformans & 一 & Unknown (adopted) & & & \\
\hline 5 & $\mathbf{A F}$ & $\mathbf{M}$ & Dejerine-Sottas disease & 一 & $\bar{\pi}$ & & & \\
\hline 6 & $\mathbf{K P}$ & $\mathbf{M}$ & Atypical muscular dystrophy & 一 & $\overline{\mathbf{F}}$ & 10 & 2 & $\square \overline{\mathrm{O}}$ \\
\hline 7 & JH & $\mathbf{M}$ & Manic depressive disorder & 一 & $\mathbf{F}$; pat $\mathbf{g} / \mathbf{f}$ & 10 & 1 & $\square \stackrel{\mathbb{2}}{2}$ \\
\hline 8 & PW & $\mathbf{M}$ & Asthma, eczema & - & $\mathbf{F}$ & 10 & & \\
\hline 9 & MP & $\mathbf{M}$ & Asthma, eczema & - & $\mathbf{M}$ & $2 \square$ & \multirow{2}{*}{\multicolumn{2}{|c|}{$2: \frac{1}{2}-0 \frac{0}{3}$}} \\
\hline 10 & NH & $\mathbf{M}$ & Asthma, eczema & - & - & $3 \square$ & & \\
\hline 11 & $\mathbf{A W}$ & $\mathbf{F}$ & Asthma, eczema & - & $\mathbf{F}$ & 10 & & כ \\
\hline 12 & GR & $\mathbf{F}$ & Asthma, eczema & 一 & - & 10 & & $\frac{F}{0}$ \\
\hline 13 & CE & $\mathbf{F}$ & Asthma, eczema & - & - & 10 & & \\
\hline 14 & SA & $\mathbf{F}$ & Asthma & 一 & $\mathbf{M} ;$ mat $\mathbf{g} / \mathbf{f}$ & $\begin{array}{ll}1 & 0\end{array}$ & 2 & $\square \widehat{亏}$ \\
\hline 15 & KC & $\mathbf{M}$ & Asthma, eczema & - & M; mother's sister's 2 daughters & 10 & $\begin{array}{l}2 \\
2\end{array}$ & $\square \div$ \\
\hline 16 & MJ & $\mathbf{M}$ & Asthma, eczema & - & $\mathbf{M}$ & $1 \square$ & 1 & 3 \\
\hline 17 & DB & $\mathbf{F}$ & Asthma, hay fever & 一 & $\mathbf{M}$ & $1 \square$ & 1 & 을 \\
\hline 18 & AW & $\mathbf{M}$ & Asthma, hay fever & - & - & 20 & & \\
\hline 19 & $\mathbf{K W}$ & $\mathbf{M}$ & Asthma & 一 & Unknown (adopted) & Unknown & & 0 \\
\hline 20 & CB & $\mathbf{F}$ & Treacher-Collins syndrome & - & F; father's brother & $1 \square$ & & \\
\hline 21 & SC & $\mathbf{F}$ & Sensorineural deafness (bil) & 一 & F; pat $\mathrm{g} / \mathrm{m}$; father's sister & 10 & & \\
\hline 22 & $\mathbf{J M}$ & $\mathbf{M}$ & Waardenburg syndrome & 一 & F; M; mat $\mathrm{g} / \mathrm{m}$ & 10 & & 을. \\
\hline 23 & *LH & $\mathbf{F}$ & Sensorineural deafness (bil) & - & M; otosclerosis & - & & $=$ \\
\hline 24 & $\mathbf{K L}$ & $\mathbf{F}$ & Sensorineural deafness (bil) & 一 & $\begin{array}{l}\text { F; pat g/f; father's brother; } \\
\text { father's brother's } 2 \text { sons }\end{array}$ & $1 \square$ & & \\
\hline 25 & JR & $\mathbf{F}$ & Sensorineural deafness (bil) & 一 & M; mat $\mathrm{g} / \mathrm{m}$; mother's sister & - & & \\
\hline 26 & *NB & $\mathbf{M}$ & $\begin{array}{l}\text { Sensorineural deafness (bil), } \\
\text { Meniere's disease }\end{array}$ & - & M; Meniere's disease & 10 & & \\
\hline 27 & MW & $\mathbf{F}$ & Sensorineural deafness (bil) & - & Mother's sister & $3 \square$ & 1 & s \\
\hline 28 & $*$ DD & $\mathbf{F}$ & Sensorineural deafness (bil) & - & F; otosclerosis & - & & Q \\
\hline 29 & $\mathbf{K J}$ & $\mathbf{M}$ & Sensorineural deafness (bil) & - & $\mathrm{M} ;$ mat $\mathrm{g} / \mathrm{m} ;$ mat $\mathrm{g} / \mathrm{g} / \mathrm{m}$ & $\begin{array}{ll}1 & 0 \\
2 & 0\end{array}$ & $\begin{array}{l}1 \\
1\end{array}$ & 믕 \\
\hline 30 & SR & $\mathbf{F}$ & Cataracts (bil) & - & $\mathbf{F}$ & $1 \square$ & & \\
\hline 31 & $\mathbf{J K}$ & $\mathbf{M}$ & Optic atrophy and nystagmus & - & - & - & & \\
\hline 32 & DB & $\mathbf{M}$ & Marfan syndrome & - & - & $3 \bigcirc$ & 1 & $\square-$ \\
\hline 33 & BC & $\mathbf{M}$ & Aniridia and nystagmus & - & - & $2 \square$ & 1 & $\mathrm{O} \overline{0}$ \\
\hline 34 & KD & $\mathbf{M}$ & $\begin{array}{l}\text { Colobomata of lens and } \\
\text { iris (bil) }\end{array}$ & - & $F$ (forme fruste) & 10 & & \\
\hline 35 & RD & $\mathbf{M}$ & 1st arch syndrome & 一 & - & $1 \square$ & 1 & $\mathrm{O} \frac{3}{10}$ \\
\hline 36 & RD & $\mathbf{F}$ & Aniridia, glaucoma & - & - & $1 \square$ & 1 & \\
\hline
\end{tabular}


APPENDIX-continued

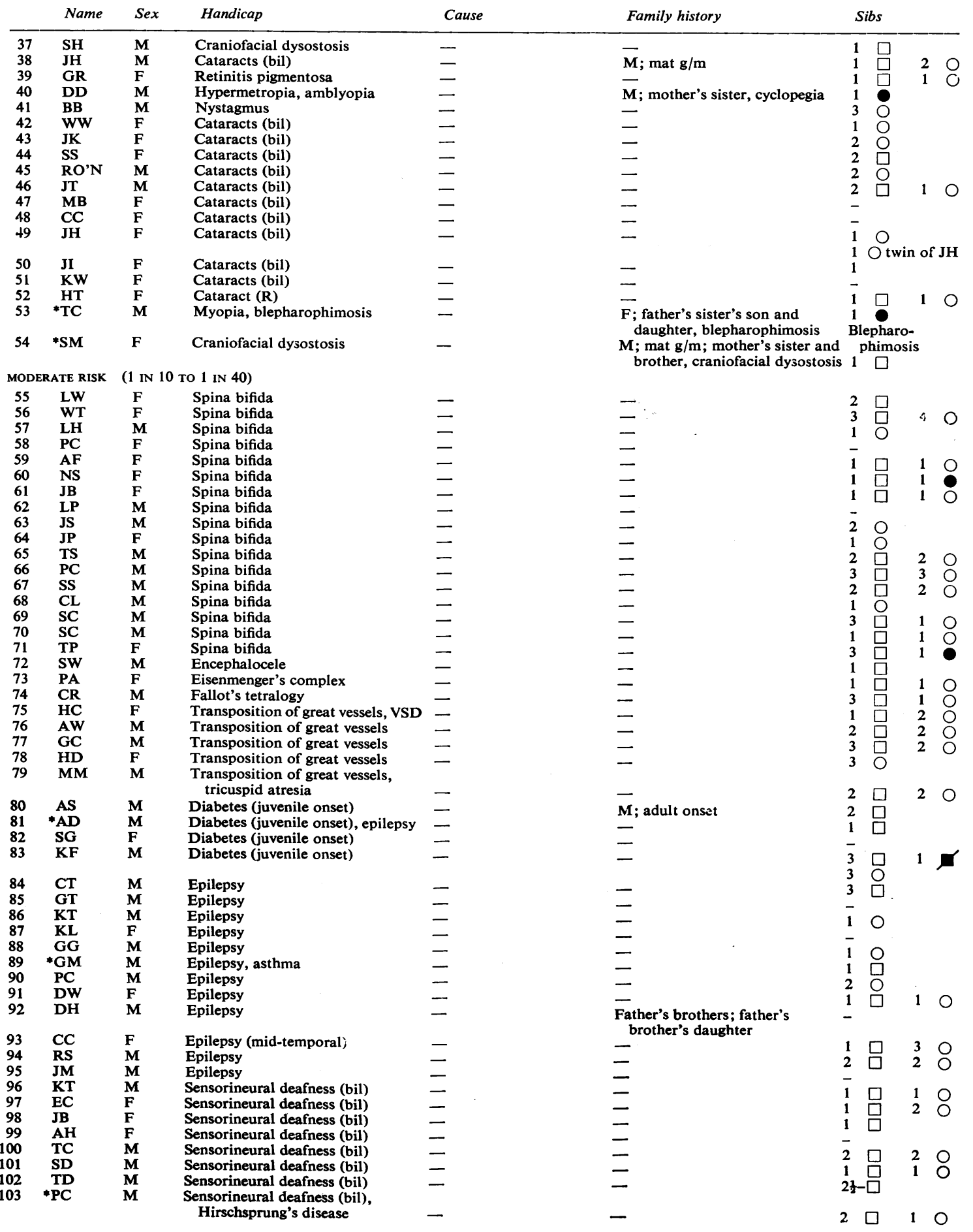


APPENDIX-continued

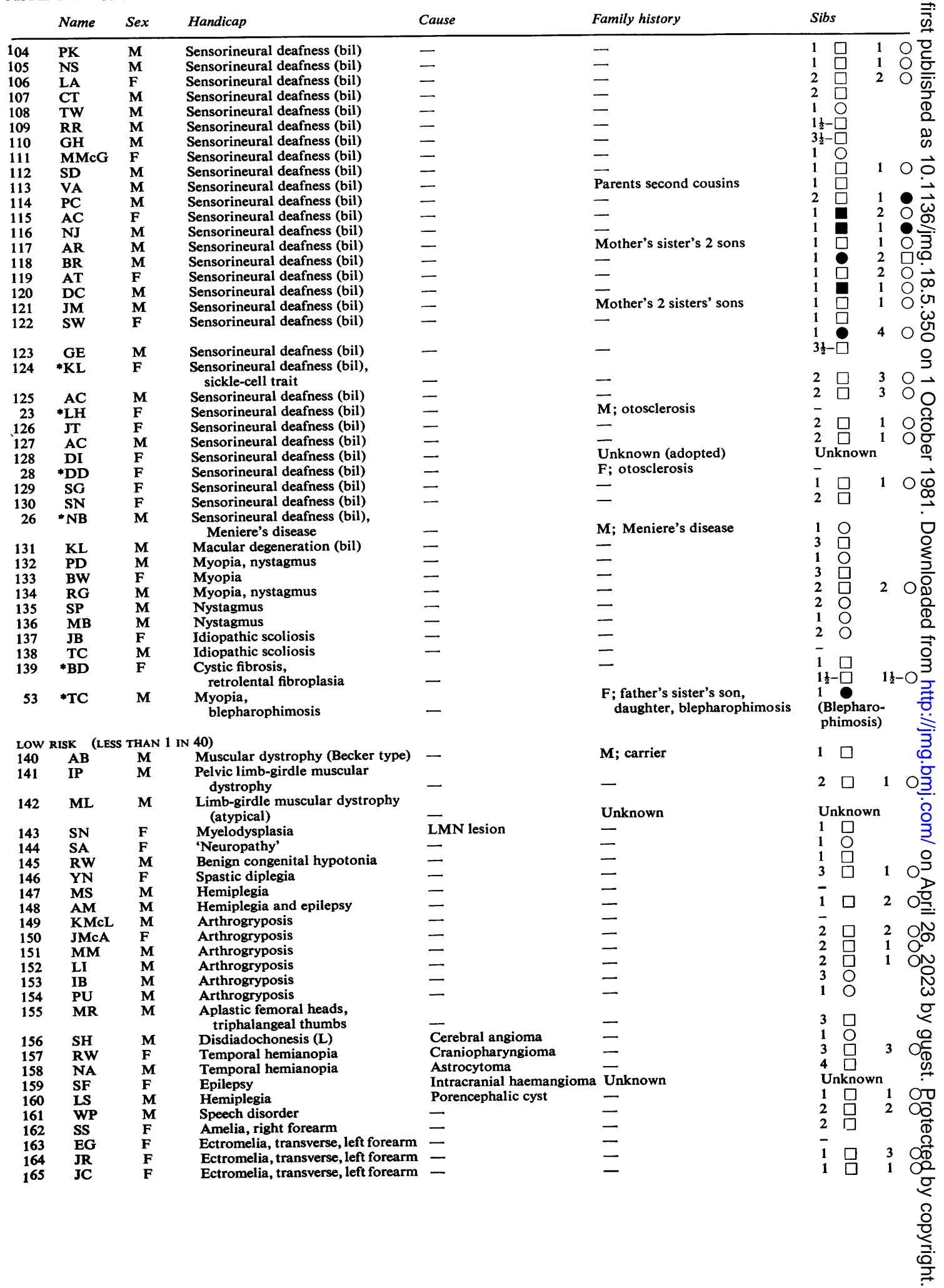


APPENDIX-continued

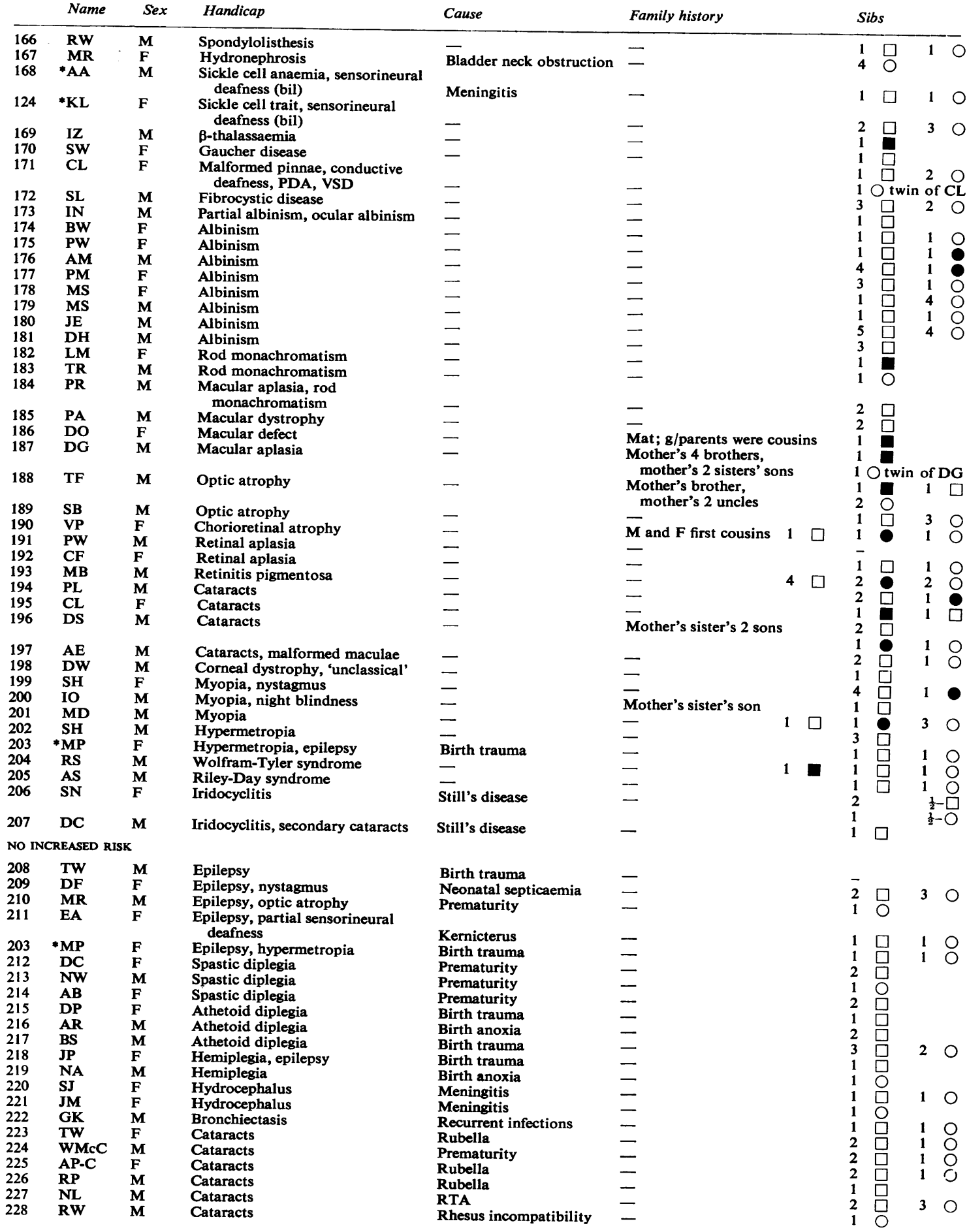


APPENDIX-continued

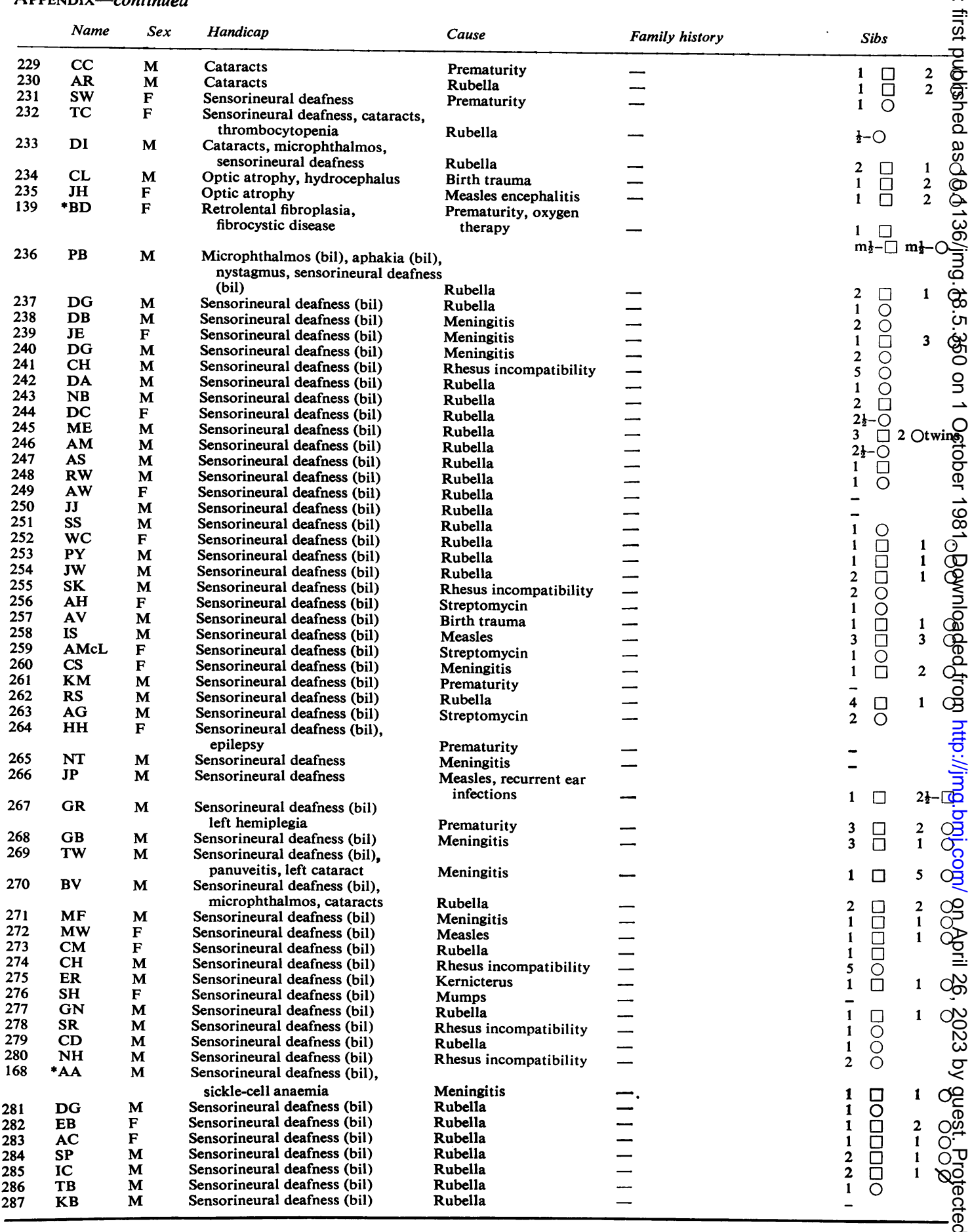

* 1 proband with 2 diagnoses. $F=$ father; $M=$ mother; $g / f=$ grandfather; $g / m$ grandmother; pat $=$ paternal; mat $=$ maternal 